OPEN ACCESS

E-ISSN : 2549-6581

Artikel Hasil Penelitian

Diterima : 2 April 2017

Direview : 5 April 2017

Dimuat : April-Juli 2017
Journal of Issues in Midwifery

\title{
Hubungan Usia Dan Lama Menopause Dengan Tingkat Kecemasan Wanita Menopause
}

\author{
Mega Ulfah ${ }^{1}$ \\ ${ }^{1}$ Midwifery Departement, Faculty of Medicine, Universitas Brawijaya, Malang, East Java, Indonesia \\ Email: megaulfah@ymail.com \\ $\mathrm{HP}+6281266279792$
}

\begin{abstract}
Based on WHO data showed that woman with menopause predicted about 373 billion in 2012 and will be 1,2 million in 2030. Psychological changingin menopause showed different symptoms, they are depression, anxiety, anger, worried etc. Those symptoms will decrease as higher of age. This study obtained to analyze relation of age and duration of menopause with level of anxiety of menopause woman. This study was an analytic study with cross sectional design. This study showed that most woman was in low anxiety category (60\%). Statistical analysis found $p=0,859$ for age and anxiety level, $p=0,222$ for duration of menopause and anxiety level. It can be concluded that there is no relation between age and duration of menopause with anxiety level of menopause.
\end{abstract}

Key words: age, duration of menopause, menopause, level anxiety

\begin{abstract}
ABSTRAK
Wanita yang mengalami menopause di seluruh dunia menurut WHO mencapai 373 juta orang di tahun 2012 dan diperkirakan akan mencapai 1,2 milyar orang pada tahun 2030. Perubahan psikologis pada masa menopause memunculkan gejala yang berbeda-beda antara lain depresi, kecemasan, mudah marah, mudah curiga, dan lain-lain. Keluhan-keluhan tersebut akansemakin jarang ditemui dengan meningkatnya usia. Penelitian ini bertujuan untuk mengetahui hubungan usia dan lama menopause dengan tingkat kecemasan wanita menopause. Penelitian ini merupakan penelitian analitik dengan desain cross sectional. Hasil penelitian didapatkan sebagian besar responden mengalami tingkat kecemasan ringan (60\%), hasil analisis hubungan usia dengan tingkat kecemasan didapatkan $p=0,859$, sedangkan analisis hubungan lama menopause dengan tingkat kecemasan didapatkan $p=0,222$. Dapat disimpulkan bahwa tidak ada hubungan usiadan lama menopause dengan tingkat kecemasan wanita menopause.
\end{abstract}

Kata kunci: usia, lama menopause, menopause, tingkat kecemasan

*Korespondensi: Mega Ulfah. Surel: megaulfah@ymail.com 


\section{PENDAHULUAN}

Total populasi wanita yang mengalami menopause di seluruh dunia menurut WHO mencapai 373 juta orang di tahun 2012 dan diperkirakan akan mencapai 1,2 milyar orang pada tahun 2030. Badan Pusat Statistik (BPS) menyimpulkan bahwa jumlah penduduk wanita berusia di atas 50 tahun meningkat dari 10,7 juta menjadi 37,3 juta orang dan diperkirakan tahun 2025 akan menjadi 75 juta orang ${ }^{1}$.

Menopause didefinisikan
sebagai berhentinya siklus menstruasi untuk selamanya bagi wanita yang sebelumnya mengalami menstruasi sebagi akibat dari hilangnya aktivitasfolikelovarium² ${ }^{2}$.

Perubahan psikis yang terjadi pada masa menopause dapat menimbulkan gejala yang berbedabeda seperti depresi, mudah tersinggung, mudah menjadi marah, mudah curiga, cemassertainsomnia.

\section{METODE}

\section{Rancangan/Desain Penelitian}

Penelitian ini menggunakan rancangan analitik observasional dengan desain cross sectional di mana variable dependen dan independen diteliti secara bersamaan.

\section{Sumber Data}

Data primer berupa usia, lama menopause dan tingkat kecemasan didapatkan secara langsung dari hasil kuesioner yang diisi langsung oleh responden.

\section{Sasaran Penelitian}

Populasi penelitian ini merupakan wanita menopause yang masih bersuami dan tidak memiliki penyakit kronis.

\section{Pengembangan Instrumen dan Teknik Pengumpulan Data}

Tingkat kecemasan diukur dengan menggunakan alat ukur HRS-A (Hamilton rating Scale For Anxiety) yang terdiri atas 14 item pertanyaan, didasarkan pada munculnya gejala pada individu dengan kecemasan.

\section{Teknik Analisis Data}

Analisa data dilakukan secara univariat dan bivariat. Analisa univariat bertujuan mendeskripsikan karakteristik umur dan lama menopause secara deskriptif dengan menghitung distribusi frekuensi. Sedangkan analisis bivariat dilakukan terhadap variabel umur, lama menopause dan tingkat kecemasan.

\section{HASIL PENELITIAN}

Hasil analisis univariat didapatkan bahwa rata-rata umur responden adalah 49 tahun dengan usia tertinggi adalah 58 tahun. Untuk lama menopause didapatkanbahwa rata-rata responden telahmengalami menopause 3 tahun, sedangkan untuk tingkat kecemasan rata-rata responden mendapatkan nilai 18 dengan kategori tingkat kecemasan ringan $(60 \%)$

$\begin{aligned} & \text { Hubungan Usia, } \\ & \text { Menopause }\end{aligned} \begin{array}{r}\text { Lama } \\ \text { dengan Tingkat }\end{array}$
Kecemasan Wanita Menopause
Hasil uji independen
didapatkan bahwa tidak ada
hubungan usia dan lama
menopause dengan tingkat
kecemasan $(p=0,859$ dan $p=0,222)$.


PEMBAHASAN

\begin{tabular}{lll}
\multicolumn{2}{l}{ Tabel 1. DistribusiFrekuensi } \\
Tingkat KecemasanWanita \\
Menopause
\end{tabular}

Tabel 2. HubunganUsia Dan Lama Menopause Dengan Tingkat KecemasanWanita Menopause

\begin{tabular}{lcll}
\hline Variabel & Rerata & SD & $\mathrm{P}$ \\
\hline Usia & 49,52 & 3,493 & 0,859 \\
Lama & & & \\
menopause & 3,60 & 1,392 & 0,222 \\
\hline
\end{tabular}

\begin{tabular}{lcr}
\multicolumn{2}{c}{ Diagnosis menopause dibuat } \\
setelah & berhentinya haid \\
(amenorea) & sekurang-kurangnya
\end{tabular} satu tahun. Berhentinya haid dapat didahului oleh siklus haid yang lebih panjang, dengan perdarahan yang berkurang. Usia seorang wanita akan mengalami menopause sangat bervariatif. Hal ini sangat bergantung pada berbagai faktor yang mempengaruhinya seperti keturunan, kesehatan umum dan pola kehidupan. Namun dapat dikatakan rata-rata seorang wanita akan mengalami menopause sekitar pada usia 45 sampai 50 tahun $^{3}$.

Rata-rata wanita mengalami menopause pada usia sekitar 50 tahun. Namun, menopause juga mungkin terjadi pada wanita muda, yaitu pada wanita yang menjalani operasi pengangkatan ovarium ${ }^{4}$.

Saat menopause terjadi perubahan tubuh wanita akibat berhentinya produksi esterogen dimana esterogen paling aktif pada jaringan yang membentuk saluran alat kelamin wanita dan payudara. Kekurangan hormon estrogen juga berpengaru hpada fungsi susunan saraf pusat, terutama terhadap suasana hati, fungsi kognitif dan sensorik serta perilaku sehingga timbul perasaan seperti mudah tersinggung, cepat marah dan merasa tertekan ${ }^{5}$.

Kecemasan merupakan

respon individu terhadap suatu keadaan yang tidak menyenangkan. Kecemasan biasanya bersumber dari ancaman integritas biologi meliputi gangguan terhadap menopausedan ancaman terhadap keselamatan diri antara lain: tidak menemukan integritas diri, tidak menemukan status dan prestise, tidak memperoleh pengakuan dari orang lain, ketidaksesuaian pandangan diri dengan lingkungan yang nyata ${ }^{6}$.

\section{KESIMPULAN}

Sebagian besar responden berada dalam tingkat kecemasan ringan (nilai 14-20). Tidak ada hubungan usia dan lama menopause dengan tingkat kecemasan wanita menopause.

\section{KONFLIK KEPENTINGAN}

Tidak ada konflik kepentingan dalam penelitian ini.

\section{DAFTAR PUSTAKA}

[1] BKKBN. 2010. Data Menopause. http://bkkbn.go.id

[2] Burger H, Dudley E, Robertson D, Dennerstein L. 2005. Hormonal Changes in Menopause Transition. The Endocrine Society

[3] Manuaba, IBG, dkk. 2010. IImu Kebidanan Penyakit Kandungan dan KB. Jakarta: EGC

[4] Asmara, Fitri. 2013. Hubungan Pengetahuan Ibu Premenopause tentang 
Menopause dengan Tingkat

Kecemasan Menghadapi

Menopause di Jorong Koto

Agung Kecamatan Sitiung

Dharmasraya Tahun 2013.

Dharmasraya

[5] Derek L, J,. 2005. SetiapWanita.

Delapratas Publishing. Jakarta

[6] Hawari, D. 2009. Manajemen

Stres, Cemas dan Depresi Edisi

2. Jakarta: FKUI. 
Journal of Issues in Midwifery, Agustus - November 2017, Vol. 1 No. 2, 1-18 